\title{
ТЕОРЕТИЧНІ ОСНОВИ УПРАВЛІННЯ ЯКІСТЮ ПРОДУКЦІЇ ЯК ОДНОГО ІЗ ОСНОВНИХ НАПРЯМКІВ ЗАБЕЗПЕЧЕННЯ КОНКУРЕНТОСПРОМОЖНОСТІ ПРОМИСЛОВИХ ПІДПРИЕМСТВ
}

\author{
Дикань О.В., к.е.н., доцент (УкрДАЗТ) \\ У статті автором розглянуто сутність поняття «управління якістю продукції» як одного із \\ основних напрямків забезпечення конкурентоспроможності промислових підприємств. Враховуючи \\ сучасні негативні тенденції розвитку промисловості Украӥни та низький рівень \\ конкурентоспроможності вітчизняної продукиії, обгрунтовано необхідність переосмислення \\ домінуючих принщипів, етапів та функиій управління якістю продукції. Виділено основні проблеми \\ впровадження прочесу управління якістю продукцї̈ на вітчизняних промислових підприємствах. Як \\ висновок, запропоновано шляхи покращення становища та подолання існуючих проблем, й зазначено, щзо \\ управління якістю це процес постійної та иүілеспрямованої роботи щэодо підвищення якості продукції \\ для забезпечення конкурентоспроможності підприємства. \\ Ключові слова: управління якістю продукцї, принципи, функції та основні етапи управління \\ якістю, конкурентоспроможність промислових підприємств.

\section{ТЕОРЕТИЧЕСКИЕ ОСНОВЫ УПРАВЛЕНИЯ КАЧЕСТВОМ ПРОДУКЦИИ КАК ОДНОГО ИЗ ОСНОВНЫХ НАПРАВЛЕНИЙ ОБЕСПЕЧЕНИЯ КОНКУРЕНТОСПОСОБНОСТИ ПРОМЫШЛЕННЫХ ПРЕДПРИЯТИЙ}

\begin{abstract}
Дикань Е.В., к.э.н., доцент (УкрГАЖТ)
В статье автором рассмотрена сущность понятия «управление качеством продукции» как одного из основных направлений обеспечения конкурентоспособности промышленных предприятий. Учитывая современные негативные тенденции развития промылленности Украины и низкий уровень конкурентоспособности отечественной продукиии, обоснована необходимость переосмысления доминирующих принцииов, этапов и функций управления качеством продукцией. Выделены основные проблемы внедрения процесса управления качеством продукиии на отечественных промышленных предприятиях. Как вывод, предложень пути улучшения положения и преодоления существующих проблем, и указано, что управление качеством это процесс постоянной и целенаправленной работь по повышению качества продукции для обеспечения конкурентоспособности предприятия.
\end{abstract}

Ключевые слова: управление качеством продукции, принципы, функции и основные этапы управления качеством, конкурентоспособность промышленных предприятий.

\section{THEORETICAL BASES OF MANAGEMENT PRODUCT QUALITY AS ONE OF THE MAIN DIRECTION OF MAINTENANCE OF INDUSTRIAL COMPETITIVENESS}

\section{Dykan O.V., Candidate of Economic Sciences, associate professor (USA of RT)}

In the article the author considered the essence of the concept of "product stewardship" as one of the main areas to ensure industrial competitiveness. Given the current negative trends in the development of industry in Ukraine and low competitiveness of domestic products, the necessity of rethinking the dominant principles, stages and functions of quality control. The main problems of implementation of the process of product quality control to domestic industrial enterprises. As a conclusion, suggest ways to improve the situation and overcome the existing problems, and stated that quality management is a process of constant and purposeful work to improve product quality to ensure the competitiveness of the enterprise.

Keywords: product quality control, principles, functions and basic stages of quality management, industrial competitiveness.

Постановка проблеми. Сучасні потребують від України глобалізаційні та інтеграційні економічні процеси конкурентоспроможності забезпечення національних 
промислових підприємств не тільки на внутрішньому, але й на світовому ринку. Як відомо, головною передумовою конкурентоспроможності підприємства $є$ якість продукції та іï оптимальна відповідність ціновій категорії. Адже при виборі продукції споживачем саме ці умови є вирішальними. Звідси й виникає необхідність постійної, цілеспрямованої роботи щодо підвищення якості продукції в порівнянні 3 аналогами конкурентів.

Необхідно відзначити й те, що підвищення якості продукції, що випускається, є одним із домінуючих напрямків зростання не тільки ефективності конкурентоспроможності продукції та підприємства, але й в значній мірі визначає престиж країни на світовому ринку, тобто $\epsilon$ вирішальним фактором збільшення національного багатства країни. Науковцями давно було визнано, що благополуччя держави залежить від наявності конкурентоспроможної вітчизняної продукції. Тому, не дивно, що дана проблема $\epsilon$ досить актуальною останні десятиліття.

Аналіз останніх досліджень та публікацій. Проблематику управління якістю відображено в працях багатьох вітчизняних та зарубіжних вчених.

Американський вчений В. Шухарт [1], якого вважають «батьком менеджменту якості», ще в 1924 р. обгрунтував, що саме організація стабільного та високоякісного технологічного процесу виробництва найбільш ефективно забезпечує отримання запланованого рівня якості, й наголосив на необхідності постійного пї покращення. Це було революційним проривом того часу.

У 1979 р. А.В. Глічев, M.I. Круглов, І.Д. Крижанівський, О.Г. Лосицький [2] визначили управління якістю продукції як постійний, планомірний, цілеспрямований процес впливу на всіх рівнях на фактори та умови, який забезпечує створення продукції оптимальної якості та повноцінне ії використання.

У 1992 р. Е. Демінг [3], учень В. Шухарта, звернувся до російських колег 3 пропозицією вирішувати всі економічні проблеми на основі системного підходу до управління якістю. Він говорив, що благополуччя країни залежить від впровадження прогресивних методів менеджменту та вмінь щодо ефективного покращення якості продукції та послуг.

Вирішенням проблем забезпечення якості продукції займалися також такі вчені як В. Федюкін [4], I. Мазур, В. Шапіро [5], В. Дикань [6], О. Криворучко [7], П. Орлов [8], Н. Лисьонкова [9] та ін.

Наукові праці 3 даної проблематики сформували чітке уявлення про поняття якості продукції, систем управління якістю, залежність ефективного функціонування підприємства від виробництва конкурентоспроможної продукції, роль міжнародних, державних стандартів та стандартів підприємства при реалізації механізму управління якістю. Також було розроблено рекомендації щодо створення та впровадження комплексних систем управління якістю продукції на підприємствах різних галузей, використання яких, на жаль, не забезпечило досягнення того високого соціально-економічного ефекту, якого очікували.

Тому, враховуючи сучасні негативні тенденції розвитку промисловості України та низький рівень конкурентоспроможності вітчизняної продукції, необхідним $\epsilon$ переосмислення домінуючих принципів, етапів та функцій управління якістю продукції, й виділення основних проблем впровадження процесу управління якістю продукції на вітчизняних промислових підприємствах, що й обгрунтувало мету даної статmі.

Виклад основного матеріалу. 3 плином часу та радикальними змінами в економічній системі, залишається незмінним вирішальний фактор забезпечення ефективності будь-яких перетворень - організація управління на всіх рівнях. На жаль, тенденцією останніх років $є$ криза управління: перехід до ринкової економіки передбачає досить таки ліберальні економічні відносини, які без належного рівня державного регулювання призвели до того, що замість чіткого самоуправління, налагодженого механізму регулювання та координації процесів, надійних горизонтальних та вертикальних зв'язків, ми отримали зниження відповідальності, ігнорування прав, погіршення організаційних відносин, розпад систем контролю на всіх рівнях управління.

Процес управління на підприємстві представляє собою планування, організацію, приведення в дію й контроль за результатами 3 метою досягнення ефективної координацію матеріальних та людських ресурсів при відповідній мотивації останніх для чіткого виконання поставлених завдань. Враховуючи те, що головною умовою ефективного функціонування підприємства $є$ виробництво конкурентоспроможної продукції високої якості, яка забезпечить задоволення потреб споживачів, то не дивно, що управлінню якістю продукції надають домінуюче значення.

Проблема забезпечення якості продукції завжди була й залишається однією 3 найскладніших задач 3 якими доводилося мати справу при виробництві продукції та наданні послуг. Дана тенденція характерна й для вітчизняних промислових підприємств, які, на жаль, розуміють цей процес як одноразовий захід, a не довгостроковий постійний стиль функціонування підприємства, що передбачає 
безупинне та максимальне покращення якості. Тому необхідно детально проаналізувати поняття «управління якістю промислової продукції», визначити основні принципи, етапи та проблеми впровадження процесу управління якістю [10].

Поняття «якість» в економічній літературі визначається як ступінь відповідності продукції встановленим стандартам та технічним умовам, що дозволяють задовольнити конкретну потребу споживача [11]. Досить точним $є$ визначення якості як комплексного поняття, яке характеризує ефективність всіх сторін діяльності підприємства: розробка стратегії, організація виробництва, маркетинг та ін. [12]. Якість товару повинна забезпечуватися на всіх етапах його створення: починаючи 3 вивчення вимог споживача та проектування товару, закінчуючи виробництвом та реалізацією готової продукції.

Сучасне трактування управління якістю сукупність принципів, методів та дій, спрямованих на досягнення оптимального рівня якості, який буде задовольняти вимогам стандартів та нормативно-технічних документів. Головним фактором управління якістю продукції $\epsilon$ профілактика, а не виправлення допущених помилок. Недоцільно очікувати кінцевого результату, оцінювати якість продукції, а потім виправляти невідповідності та відхилення від запланованого рівня. Для досягнення заданих цілей необхідно впливати на сам процес виробництва з метою економії як матеріальних та фінансових ресурсів, так i часу виходу нової продукції. Тобто управління якістю продукції не може бути ефективним після того як продукція уже вироблена, це повинно передувати самому процесу виробництва та здійснюватися безперервно в ході його протікання.

Варто відзначити, що вирішення задачі забезпечення високого рівня якості потребує комплексного, системного підходу. Виділимо основні принципи, функції та етапи управління якістю продукції.

Процес управління якістю продукції базується на наступних основних принципах:

- оріснтація на споживача - саме споживач визначає напрямок виробництва;

- цілеспрямованість - необхідно чітко визначити необхідний рівень якості, якого ми прагнемо досягти;

- комплексність - визначення сукупності заходів, які ми плануємо здійснити для забезпечення заданого рівня якості, враховуючи фактори як внутрішнього, так і зовнішнього середовища;

- системний підхід - реалізується через формування та забезпечення ефективного функціонування системи управління якістю;
- перспективність - необхідно планувати діяльність по управлінню якості не тільки на короткий термін, але й на довгострокову перспективу, враховуючи подальше та постійне вдосконалення якості;

- оптимальність - досягнення оптимального співвідношення «якість-ціна» 3 метою максимального задоволення вимог споживача.

Управління якістю продукції - це безперервний та замкнутий цикл, який включає в себе декілька основних етапів: аналіз ринкового середовища, аналіз теоретико-методологічної та практичної бази щодо управління якістю й створення та впровадження системи управління якістю продукції на довгострокову перспективу. Більш детально дані етапи розкрито на рисунку 1.

У сучасній літературі існує безліч підходів до визначення основних функцій управління підприємством. Однією з найбільш поширеніших є наступна класифікація: планування - організація мотивація - контроль. Планування є головною функцією, яка передбачає прогнозування, постановку цілей та завдань функціонування підприємства, тобто визначає вид діяльності, тип продукції, яка буде випускатися, та категорію населення, яка буде виступати споживачем продукції. Організація - розподіл відповідальності між основними підрозділами підприємствами для ефективної та скоординованої роботи. Тобто означає цілеспрямований вплив на колектив для створення механізму управління ним та зворотного зв'язку. Дана функція передбачає делегування повноважень. Мотивація передбачає формування ідеалів людини, реалізацію колективних потреб, підвищення рівня задоволення виконанням роботи, оцінку виконаної праці, впровадження різноманітних способів стимулювання до виконання обов'язків на найвищому професійному piвні. Контроль - це процес забезпечення досягнення цілей організації. Так як планування направлено у майбутнє, то така функція як контроль повинна передбачати та попереджувати зміни. Контроль $є$ тією постійною профілактичною діяльністю управлінського процесу для нормалізації його діяльності, про що було сказано вище. Також, доцільно виділити ще одну функцію корисності, що передбачає аналіз відгуків покупців щодо якості продукції. післяпродажного обслуговування, та визначення ступеня задоволення, яке отримує споживач від споживання продукції. Усі функції та принципи управління якістю взаємопов'язані між собою, що зображено на рисунку 2. 


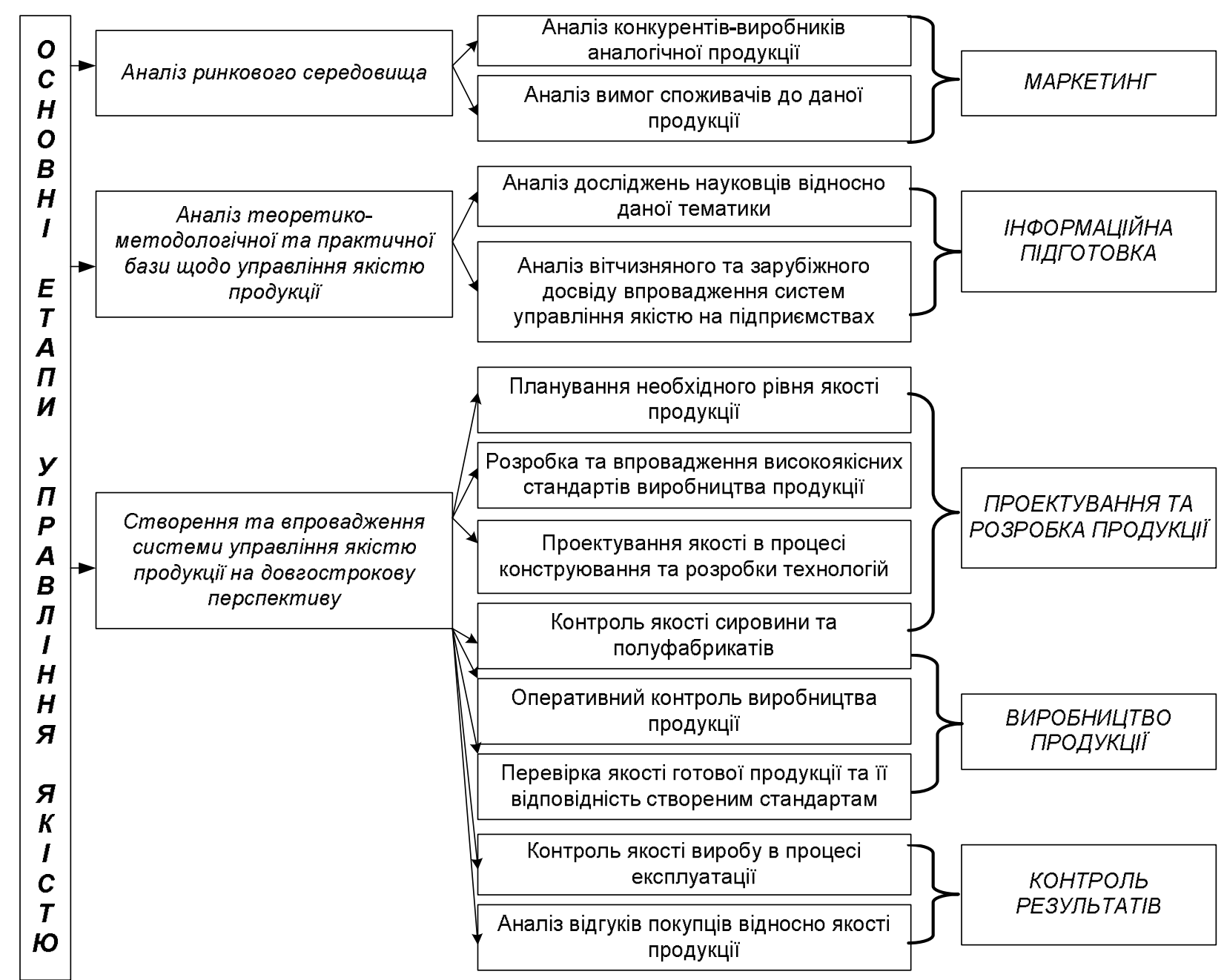

Рис. 1. Основні етапи управління якістю продукиії

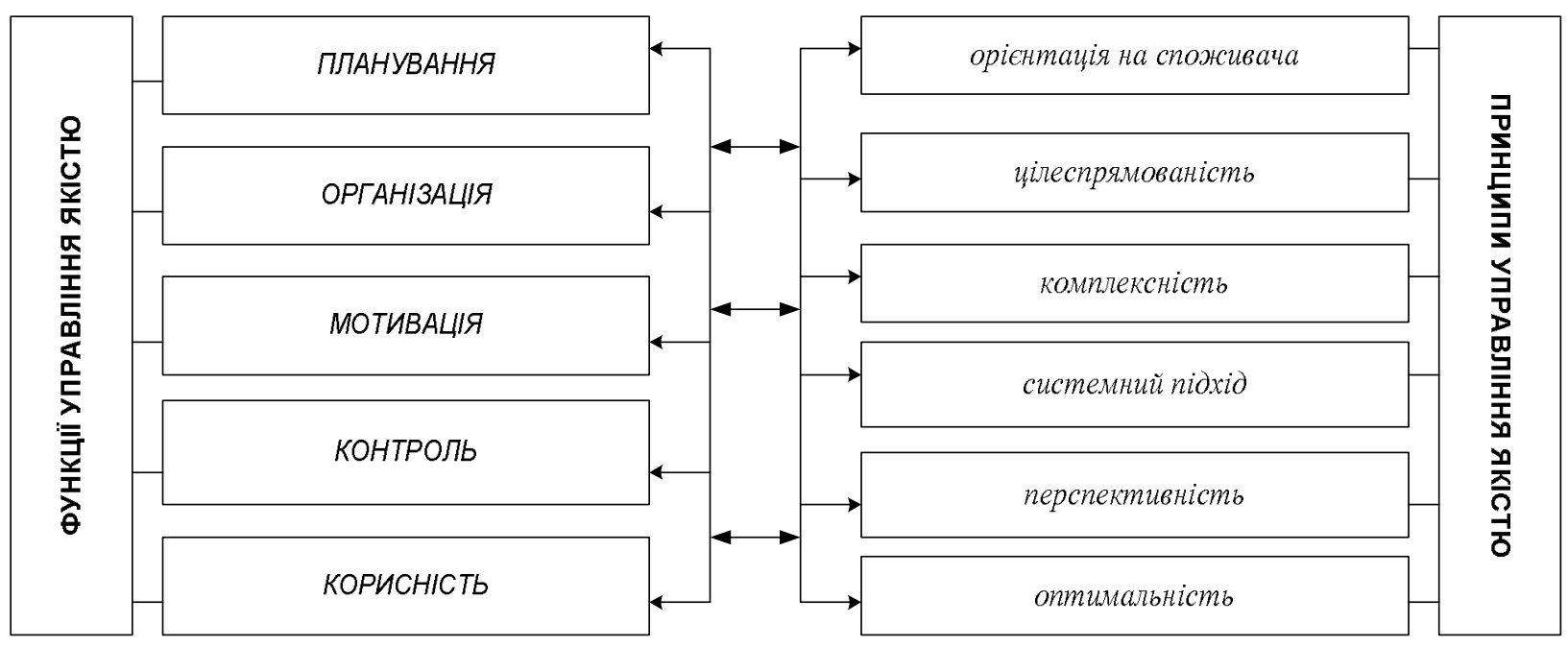

Рис.2. Функиії та принциии управління якістю 
На жаль, більшість підприємств на даний момент не мають можливостей впровадження систем управління якістю та обмежуються контролем якості продукції, яку вони виробляють. Пояснюється це перш за все відсутністю фінансових ресурсів. Адже, дані підприємства не мають коштів навіть на оновлення матеріально-технічної бази, не говорячи уже про фінансування інновацій в області управління. Також, можна виділити ще ряд проблем, які пов'язані з впровадженням систем управління якістю продукції на підприємствах:

- поняття «якість» сприймається багатьма керівниками як ступінь відповідності готової продукції технічним умовам та вимогам до процесу виробництва. Дане тлумачення застаріле й характерне для часів командно-планової економічної системи. 3 плином часу та переходом до ринкової економічної системи, змінилось й ставлення до якості продукції. Тепер недостатньо, щоб продукція тільки відповідала встановленим стандартам якості, необхідно дотримання й інших вимог: поставка продукції «точно в строк», максимальна ступінь задоволення споживачів даної продукції, гарантія та сервісне обслуговування і т.д. Тобто, споживач $є$ тією точкою відліку, яка визначає, яку продукцію, якої якості та в якій кількості повинні виготовляти підприємства. А, враховуючи, високий ступінь конкуренції на ринку, ця проблема стоїть досить гостро;

- відсутність необхідної теоретикометодологічної та практичної бази в сфері управління якістю. Більшість наукових праць даної тематики відносяться до 60-90 pp. ХХ ст., а сучасні дослідження приймають їх за основу, лише доповнюючи та корегуючи. Постає питання аналізу зарубіжного та вітчизняного досвіду для створення ефективної системи управління якістю, враховуючи уже зроблені помилки;

- нестача кваліфікованих спеціалістів в області забезпечення якості продукції. Ця проблема повинна вирішуватися на державному рівні шляхом створення бюджетних місць в вищих навчальних закладах;

- «показове» впровадження систем управління якістю продукції 3 метою отримання сертифікатів, підвищення іміджу підприємства на ринку, а не для покращення ефективності управління якістю. Необхідно постійно вдосконалювати не тільки якість продукції, а й функціонування підприємства;

- недосконалість та можливість двоякого трактування наявних нормативно-правових актів, що регулюють процес управління якістю;

- корумпованість державних служб, що контролюють діяльність підприємств;

- відсутність повної та чіткої відповідальності керівництва підприємства за належне виконання норм та стандартів при виробництві продукції;

- недостатня мотивація персоналу для виготовлення якісної продукції;

- відсутність чітко сформульованої та ефективної системи управління якістю продукції та належного ії застосування.

- недосконалість сертифікації систем якості на відповідність ISO: 9001.

Висновки. Проведений аналіз сучасного стану забезпечення якості продукції на вітчизняних підприємствах показав, що є досить багато проблем, які перешкоджають цьому процесу та, відповідно, підвищенню конкурентоспроможності вітчизняної промислової продукції. Покращити становище та подолати проблеми можна, але, на даному етапі, це залежить від активного втручання держави, а саме: навчання спеціалістів в галузі управління якістю за рахунок державного замовлення; проведення тренінгів та семінарів на загальнодержавному рівні для роз'яснення сутності, необхідності впровадження та основних положень систем управління якістю; удосконалення нормативноправової бази в галузі управління якості продукції; надання фінансової підтримки вітчизняних підприємств (організацій, установ) на вигідних умовах для підприємств; використання ефективних систем стандартизації та сертифікації продукції.

\section{СПИСОК ЛІТЕРАТУРИ}

1 Шухарт В. Экономическое управление качеством промышленной продукции: книга / В. Шухарт. - 1931. - С. 38-39.

2 Гличев А.В. Управление качеством продукции (опыт, проблемы, перспективы) / А.В. Гличев, М.И. Круглов, И.Д. Крыжановский, О.Г. Лосицкий. - М.: Экономика, 1979. - 175 с.

3 Обращение доктора Деминга к СНГ / Курс на качество. - 1992. - № 1. - С. 3-5.

4 Федюкин В. Управление качеством производственных процессов: учеб. пособ. для вузов / В. Федюкин. - 2-е изд. - М.: Кнорус, 2013. $230 \mathrm{c}$.

5 Мазур И.И. Управление качеством: учеб. пособие для студ. вузов. / И.И. Мазур, В.Д. Шапиро.- 2-е изд. - М.: Омега-Л, 2009. - 400 с.
6 Дикань
В.Л.
Обеспечение конкурентоустойчивости предприятия: монография / В.Л. Дикань. - Харьков: «Основа», 1995. - 160 с.

7 Криворучко О.М. Менеджмент якості на підприємствах: теорія, методологія і практика: монографія / О.М. Криворучко. - Харків: ХНАДУ, 2006.- 404 c.

8 Орлов П.А. Впровадження систем управління якістю: стан, проблеми, перспективи / П.А. Орлов // Стандартизація. Сертифікація. Якість. - 2004. - № 6. - С. 59-63. 
9 Лисьонкова Н.М. Сучасні системи управління якістю продукції / Н.М. Лисьонкова, В.Л. Дикань // Вісник економіки транспорту та промисловості: збірник наук.-практ. ст. - Х.: УкрДАЗТ, 2005. - Вип. 12. - С. 229 - 235.

10 Дурнев В.Д. Экспертиза и управление качеством промышленных материалов / В.Д. Дурнев, С.В. Сапунов, В.К. Федюкин. - Питер, 2004. - $253 \mathrm{c}$.

11 Іванілов О.С. Економіка підприємства: підручник / О.С. Іванілов. - К.: Центр учбової літератури, 2009. - 728 c.

12 Тимошенко В.М. Економіка якості: конспект лекцій / B.М. Тимошенко. - Харків: ХНАМГ, 2010. -90 c.

13 Листопад I.O. Сутність та проблеми впровадження системи управління якістю на підприємствах [Електронний ресурс] / I.О. Листопад, І.В. Гудима. - Режим доступу: http://khntusg.com.ua/files/sbornik/vestnik_1072/29.pdf

14 Свтушевський В. Сучасний стан та проблеми забезпечення якості продукції на вітчизняних підприємствах [Електронний ресурс] / В. Євтушевський, Г. Махініч. - Режим доступу: http://khntusg.com.ua/files/sbornik/vestnik_1072/29.pdf

15 Момот O.I. Проблеми сертифікації систем якості: навчальний посібник / О.I. Момот. Донецьк: ДонГТУ, 2000. - 120 с.

16 Кане М.М. Системи, методи та інструменти менеджменту якості / М.М. Кане. Київ, 2009. - 559 с.

Рецензент д.е.н., професор УкрДАЗТ Компанієць В.В. Експерт редакційної колегії к.е.н., доцент УкрДАЗТ Токмакова І.В.

\title{
УДК 331.108.2
}

\section{УДОСКОНАЛЕННЯ СИСТЕМИ УПРАВЛІННЯ ПЕРСОНАЛОМ В УМОВАХ РОЗВИТКУ ПІДПРИЕМСТВА}

\author{
Каличева Н.С., к.е.н., доцент, \\ Стецюк М.I., магістр (УкрДАЗТ)
}

У статті розглянуто проблему загострення ринкової конкурениії в умовах глобалізації економіки та інтеграції України у світову економічну систему, щзо вимагає від вітчизняних суб'єктів господарювання визначати стійки конкурентні переваги та здійснювати виробничу діяльність більи ефективно, ніж конкуренти. Визначено, щзо одним з найважливіших ресурсів є персонал організації, зі своїми навичками, вміннями, кваліфікацією та ідеями. Також у статті виділено основні функції та принциипи управління персоналом.

Ключові слова: розвиток підприємства, персонал, мотивація, трудові відосини, принципи управління, ефективність управління персоналом.

\section{СОВЕРШЕНСТВОВАНИЕ СИСТЕМЫ УПРАВЛЕНИЯ ПЕРСОНАЛОМ В УСЛОВИЯХ РАЗВИТИЯ ПРЕДПРИЯТИЯ}

\author{
Каличева Н.Е., к.э.н, доцент, \\ Стецюк М.И., магистр (УкрДАЗТ)
}

\begin{abstract}
В статье рассмотрена проблема обострения рыночной конкуренции в условиях глобализачии экономики и интеграции Украины в мировую экономическую систему, что требует от отечественных субъектов хозяйствования определять стойки конкурентные прецмущества и осуществлять производственную деятельность более эффективно чем конкуренты. Определено, что одним из важнейших ресурсов является персонал организащии со своими навыками, умениями, квалификацией и идеями. Также в статье выделены основные функции и принципы управления персоналом.
\end{abstract}

Ключевые слова: развитие предприятия, персонал, мотивация, трудовые отночения, принципь управления, эффективность управления персоналом.

(C) Каличева Н.Є., Стецюк M.I.
Вісник економіки транспорту і промисловості № 49, 2015 